Abstracta Iranica Abstracta Iranica

Revue bibliographique pour le domaine irano-aryen

Volume 24 | 2003

Comptes rendus des publications de 2001

\title{
jaras e pox̌to, nazm nambar. Karachi, 2001, 1434 p. [Numéro spécial de la revue jaras e pox̌to, consacré au naẓm]
}

\section{Nadjib Manalaï}

\section{OpenEdition}

Journals

\section{Édition électronique}

URL : http://journals.openedition.org/abstractairanica/34864

DOI : 10.4000/abstractairanica.34864

ISSN : 1961-960X

Éditeur:

CNRS (UMR 7528 Mondes iraniens et indiens), Éditions de l'IFRI

\section{Édition imprimée}

Date de publication : 15 mai 2003

ISSN : 0240-8910

\section{Référence électronique}

Nadjib Manalaï, « jaras e pəx̌to, nazm nambar. Karachi, 2001, 1434 p. [Numéro spécial de la revue jaras e pəx̌to, consacré au naz̦m] », Abstracta Iranica [En ligne], Volume 24 | 2003, document 310, mis en ligne le 05 janvier 2010, consulté le 25 septembre 2020. URL : http://journals.openedition.org/ abstractairanica/34864 ; DOI : https://doi.org/10.4000/abstractairanica.34864

Ce document a été généré automatiquement le 25 septembre 2020.

Tous droits réservés 


\title{
jaras e pəx̌to, nazm nambar. Karachi, 2001, 1434 p. [Numéro spécial de la revue jaras e pax̌to, consacré au naẓm \\ 1
}

\author{
Nadjib Manalaï
}

1 jaras e pəx̌to («Cloche du pachto ») est l'une des rares revues pachto d'une longévité remarquable. Ce trimestriel littéraire est publié à Karachi depuis 1992. Ce numéro spécial paru fin 2001 vient en remplacement des numéros 37 à 40 (janvier 2001 à mars 2002).

2 Dans la terminologie littéraire afghane le mot naẓm (vers) s'oppose à nasr (prose) tandis que dans la terminologie littéraire pakistanaise nazm décrit d'une manière plus restrictive le poème dont les vers ont une continuité sémantique (contrairement au gazal dont les beyts sont indépendants).

3 Les auteurs décrivent le nażm pachto à travers cinq mouvements (périodes) historiques quelque peu artificiels :

4 - La première période commence avec Khoshal Khattak (1613-1689) et se poursuit jusqu'à la fin du $18^{\mathrm{e}} \mathrm{s}$.

5 - La seconde période commence avec le colonialisme britannique et se termine par la partition de l'Inde.

6 - La troisième période débute avec la création du Pakistan et se poursuit jusqu'à la révolution d'avril 1978 en Afghanistan.

7 - La quatrième période s'ouvre en 1970 et s'achève avec le démantèlement de l'URSS.

8 - La cinquième période commence en 1985.

9 Chaque période est étudiée à travers quelques articles de spécialistes et illustrée par des exemples de poésies. Ainsi plus de 80 chercheurs contribuent à faire connaître l'œuvre de plus de 250 poètes. Les poètes afghans sont présents, mais sous-représentés. 
10 Malgré une présentation touffue, et la qualité inégale des analyses, l'ouvrage constitue un outil indispensable pour comprendre la poésie pachto contemporaine.

INDEX

Thèmes : 11.2. Littérature pashto et dari (Afghanistan)

\section{AUTEURS}

NADJIB MANALAII

INaLCO - Paris 